\title{
Security Institutions in Greater Eurasia: Implications for Russia ${ }^{1}$
}

\author{
A. Korolev, V. Shumkova
}

Alexander Korolev - Research Assistant, Centre for Comprehensive European and International Studies, National Research University Higher School of Economics; post-graduate student, NRU HSE; 17 Malaya Ordynka Str., 119017, Moscow, Russian Federation; E-mail: askorolev@hse.ru

Veronika Shumkova - Research Assistant, Centre for Comprehensive European and International Studies, National Research University Higher School of Economics; 17 Malaya Ordynka Str., 119017, Moscow, Russian Federation; E-mail: vshumkova@hse.ru

\begin{abstract}
In this article, the authors analyze the current state and prospects for the development of key institutions in the field of regional security in Eurasia. ASEAN-led mechanisms and the Eurasian "continental" formats, represented by the Shanghai Cooperation Organization (SCO) and the Collective Security Treaty Organization (CSTO) have been chosen as a case-study.

Special focus is put on the possibility of connecting Russia with multilateral security initiatives in Eurasia in terms of promoting Russian strategic interests, as well as realizing the potential of the SCO as a structural pillar of the emerging geostrategic space - Greater Eurasia.

The authors conclude that the current state of regional institutions in the field of security does not fully correspond to Russia's interests due to the institutional limitations of multilateral formats.

According to the authors, the main reason why the ASEAN-led dialogue platforms on security issues are not able to realize its potential in addressing main challenges is the nature of the principles of ASEAN cooperation that hamper the process of making a collective decision.

Regarding the SCO, the authors believe that the key problem in the foreseeable future may be the achievement of consensus among the participating states after the enlargement (the accession of India and Pakistan) and, as a consequence, the need to transform the institutional format to new realities.

In conclusion, the authors argue that in the long-term perspective the development of the institutional environment of Greater Eurasia for the purpose of ensuring regional security should be carried out through close coordination between the SCO and other security formats - the CSTO and the ASEAN-led dialogue structures.
\end{abstract}

Key words: Greater Eurasia; Russia; SCO; CSTO; ASEAN; EAS; ARF

For citation: Korolev A., Shumkova V. (2018) Security Institutions in Greater Eurasia: Implications for Russia. International Organisations Research Journal, vol. 13, no 3, pp. 70-81 (in English). DOI: 10.17323/1996-7845-2018-03-04.

${ }^{1}$ The editorial board received the article in October 2017.

The article has been supported by a grant of the Russian Science Foundation. Project No. 17-18-01577 "Creation of Greater Eurasia and the Development of Strategy for Bilateral Cooperation Between Russia and Regional Countries.” 
Greater Eurasia is a place where the interests of not only great, but also medium and minor powers clash. South Asia faces a number of lingering political and ethnoconfessional conflicts and disputes among major countries in the region, coupled with the growing threat to all regional powers from nonstate actors, specifically radical Islamic structures.Deepening contradictions between India and China are taking centre stage as they are critical for the development of India's military capabilities. In addition to the territorial conflict in Tibet, the two countries are creating additional pockets of tension by getting involved in conflicts in the Maldives and Sri Lanka.

India, which is seeking recognition of its great power status, is actively advancing the concept of an Indo-Pacific region which is essentially anti-Chinese in nature.

Apart from purely intraregional rifts, there is another problem, namely the rapid internationalization of the South China Sea as the United States and Japan - which are not directly involved in the territorial conflict - have become engaged in its resolution. With Donald Trump in the White House, the standoff at sea between China and the U.S. has reached a new level. While a direct armed conflict between the two countries was considered practically impossible several years ago, a local armed clash between them has become more probable, giving experts new food for thought.

Finally, another serious challenge in Greater Eurasia is the spread of nontraditional security threats such as cyberattacks, piracy in the Strait of Malacca, and illegal drug, nuclear arms and technology trafficking. All these factors may prod countries into building up their military-technical potential and gradually modernizing their navies. This in turn may further increase regional tension.

Coupled with nontraditional security challenges, the growing competition between the U.S. and China in Greater Eurasia (which has become more explicit and systemic after Donald Trump's election) is spurring demand for multilateral institutions and an active and less dependent arbiter and security supplier. This creates an additional "window of opportunity" for Russia to expand its influence in multilateral institutions in Eurasia.

\section{Key Security Institutions and Formats in Greater Eurasia}

While there is an abundance of economic regulatory institutions and formats, a developed and inclusive institutional environment is clearly lacking in the field of security. There are two main types of security in Greater Eurasia. The first group includes formats developing around the Association of Southeast Nations (ASEAN), the East Asia Summit (EAS), the ASEAN Regional Forum (ARF) and others. The second group consists of Eurasian formats that we can tentatively call "continental," represented by the Shanghai Cooperation Organisation (SCO) and the Collective Security Treaty Organization (CSTO).

It is assumed that the institutional environment for a comprehensive partnership should also incorporate ASEAN-based formats [President of Russia, 2017]. However, at present most of the ASEAN+ security formats are focused on the Asia-Pacific Region (APR), while some include the U.S. and other Pacific states. It is necessary to find 
out whether these formats can be effectively fitted into the integration process evolving within the comprehensive Eurasian partnership. Multilateral dialogues actively promoted by ASEAN - the EAS, ARF and the expanded ASEAN Defense Ministers' Meeting (ADMM-Plus) platform for ASEAN and its eight dialogue partners - are of great importance. New regional security trends have had a major impact on the ability of ASEAN-centric security dialogues to achieve their goals and objectives. A big part of their agenda has been implemented only partially or not at all. The ARF, the EAS and the ADMM-Plus have been successful in specific areas but have made little progress on strategic issues.

For example, the territorial conflict in the South China Sea has been addressed within ASEAN-centric dialogues many times but no significant results have been achieved. Little has been done in practical terms to resolve the issue since the Declaration on the Conduct of Parties in the South China Sea was signed in 2002. In the fall of 2011, ASEAN countries decided to start drafting a code that could subsequently provide the basis for negotiations with China [Lokshin, 2013, p. 29]. However, this work was suspended in 2012 after the protest of Cambodia, president of ASEAN at the time. Since then the parties have repeatedly reaffirmed their desire to work out and sign a legally binding code as soon as possible (for example, at the 18th ASEAN-China Summit in November 2015), but no firm steps have been taken over the past 15 years to resolve the issue. Since China objects to discussion of the sensitive South China Sea issue in ASEAN-centric dialogue formats, one can assume that ASEAN structures simply do not have enough resources to settle the issue.

The main conclusion arising out of the aforementioned discussion is that ASEAN's key cooperation and conflict resolution principles cannot effectively settle some of the major disagreements in the region. This suggests that there is only a limited ability for ASEAN-centric formats which operate on the basis of these principles to reduce the level of conflict in the region.

In our opinion, the main reason ASEAN-centric security formats cannot fully use their potential to achieve their goals is the nature of the principles of cooperation within ASEAN. The principle of consensus appears to be the biggest problem. Some researchers insist that it limits possibilities for cooperation [Mikhnevich, 2016, p. 114]. Abortive attempts by the ASEAN foreign ministers to adopt a joint communiqué at their meeting in 2012 clearly show how the principle of consensus can thwart the adoption of constructive decisions. The ministers failed to come to an agreement because Cambodia insisted on revising the preliminary text of the Declaration on the Conduct of Parties in the South China Sea to delete references to China's activities off Vietnam's exclusive economic zone and the Scarborough Shoal, thus predictably raising objections from the Philippines and Vietnam [Thayer, 2013, p. 78]. Cambodia, acting under strong pressure from China (in 2012 China was its main importer), used the principle of consensus to block the adoption of the final document. This was an unprecedented event in the history of ASEAN.

On the whole, this shows how easily one can use this principle to manipulate the agenda and the decision-making process. It is the principle of consensus that allows 
China to prevent discussion of issues related to territorial disputes in the South China Sea in ASEAN-centric formats.

The principle of consensus is also a major obstacle in the work of multilateral ASEAN-centric security formats because it requires all parties participating in the discussion, even those that are not directly involved in the matters being discussed, to be in agreement. This creates a situation in which countries with no direct interest in a conflict can influence the process by invoking the principle of consensus.

Although ASEAN-centric multilateral formats are presented as the main mechanisms for resolving security issues in the Asia-Pacific region, there is much doubt about their effectiveness because of the ASEAN consensus-building method. On the one hand, the proposed ASEAN principles of cooperation as fundamental guidelines for the operation of ASEAN-centric platforms mean comfortable participation of states, free from pressure from other parties. On the other hand, these principles can significantly impede work and make it less effective.

There are many indications that the development of security cooperation in Greater Eurasia can give a new strong impetus to the ARF, the EAS and the ADMMPlus. First, it is obvious that the rapidly increasing economic cooperation in such a large area should be backed up by structures that can ensure safe implementation of economic projects. ASEAN-centric multilateral formats appear to be the best fit for this role as they incorporate many countries already engaged in European projects, and have well-functioning mechanisms for communication, summitry and joint seminars, as well as channels for exchanging information, expertise and specialists. On the other hand, protection of economic initiatives can make these formats more cohesive as most of their participants pursue a common goal of promoting regional development. This will make members more interested in the effective work of the ARF, the EAS and the ADMM-Plus and allow them to carry out necessary reforms.

Second, engagement in Eurasia will enable ASEAN-centric multilateral formats to expand and develop their cooperation agenda so that, by dealing with common security threats, states will be able to reach a new level of trust, notwithstanding subregional disagreements. International terrorism, which affects all Eurasian states in one way or another, is one such common threat. Since the terrorist threat is global and no one country can deal with it alone, one can assume that all states should be more than interested in coordinating their counterterrorist activities. Russia's Foreign Policy Concept says that the fight against terrorism requires effective and systemic joint work between countries and the international community [Ministry of Foreign Affairs of Russia, 2016]. The ASEAN Political Security Community Blueprint covering a period of up to 2025 also puts emphasis on stronger cooperation between states and regions in order to fight terrorism [ASEAN, 2015, p. 35]. The agenda of ASEAN-centric formats includes counterterrorist cooperation, but this cooperation can be effective only if it is extended to the whole of Eurasia. In our opinion, ASEAN-centric multilateral formats should conduct the fight against terrorism in Eurasia through active cooperation with the SCO and the CSTO. 
On the whole, objective processes accompanying the development of ASEAN dialogue formats suggest that effective work to ensure security in Greater Eurasia will require the engagement of ASEAN-centric structures in the comprehensive economic partnership, at a minimum. ASEAN can be very helpful in strengthening the institutional environment in the region if it engages with the Eurasian Economic Union and the SCO. Naturally, its work in these organizations will not be very effective at the initial stage due to the specific nature of their negotiating processes, but its engagement will be the first step towards developing a concrete security agenda for the region.

The Shanghai Cooperation Organisation, unlike ASEAN+ formats, is not overburdened with external participants (primarily the U.S.) and can most likely provide the main institutional framework for the security system in Greater Eurasia. SCO enlargement can both create new challenges and open up opportunities to strengthen its role as a key security institution in Greater Eurasia.

After admitting India and Pakistan at its 17th summit in Astana on 8-9 June 2017, the SCO has transformed itself into an organization that includes four nuclear states, two major economies and almost half of the world's population. This allows some experts to speak of a "Shanghai Group of Eight" as a Eurasian alternative to the West's Group of Seven [Cherian, 2017]. A broader membership strengthens the SCO's authority, making it the only organization that has sufficient potential to become the backbone of the security architecture in Greater Eurasia.

The development of the SCO's potential is very important for building a stable institutional space in Greater Eurasia. Considering growing security threats in the region, primarily nontraditional ones such as international terrorism, cyberattacks and information warfare, continuing and effective cooperation in this area is crucial for maintaining stability in the region. This is borne out by the statement on joint counteraction to international terrorism [SCO Secretariat, 2017] and the Convention on Countering Extremism [SCO Secretariat, 2017] signed at the latest SCO summit, both of which aim to strengthen the Organisation's counterterrorism agenda.

But the SCO is experiencing a number of structural problems which restrict its further development.

First, reaching a consensus among members after enlargement may be a potential problem. On the one hand, the admission of India and Pakistan has boosted its potential significantly as a key security institution in Eurasia. In fact, a broader membership gives the Organisation more opportunities to act in such areas as counterterrorism, cooperation on Afghanistan or the fight against organized crime and drug trafficking. It can also prompt an agenda for "hard" security or at least its substantive discussion, especially in light of the conflicts between some of the members.

The approval of the new SCO admission rules in 2015 and the accession of India and Pakistan create new opportunities for further enlargement and admission of new regional players. In their discussions on the summit's sidelines, SCO leaders talked about a possible admission of Iran [Reuters, 2017], which would make the SCO an important player in the conflict-ridden Middle East. While earlier this was impossible due 
to the formal admission criteria (a candidate country could not be under UN Security Council sanctions), the international community started to lift sanctions on Iran as of early 2016 and all obstacles may be removed in the foreseeable future.

On the other hand, a broader SCO membership has increased disagreements within the Organisation (including old ones between India and China and between India and Pakistan). India and China are locked in territorial disputes with each other and continue their fierce competition for influence in South Asia. India supports China's opponents in its dispute over the South China Sea. There are other lingering territorial disputes between Uzbekistan and Kyrgyzstan (almost a quarter of their shared border has not been delimited) and between Uzbekistan and Tajikistan (about 20\% of the border between them remains undelimited), which provoke incidents on their borders.

There is no consensus among the "old members" - key SCO countries - on which areas of cooperation need to be developed. Unlike Russia, China believes that priority should be given not only to military and political aspects but also to economic considerations. In 2010, China pushed for the creation of an SCO development bank, raising unambiguous doubts in Russia. Moscow then suggested reorganizing the Eurasian Development Bank into a SCO development bank, a proposal that received little support, particularly from China [Denisov, Safranchuk, 2016].

This explains China's uneven interest towards the Organisation. Officially, China has always spoken of its importance, but expert assessments varied. China's doubts about the SCO stem from the fact that the country has largely redirected its activities in the region towards the One Belt, One Road initiative. It is not clear whether China will be interested in creating a SCO development bank since similar structures, such as the Asian Infrastructure Investment Bank or the New Development Bank established by the BRICS grouping of Brazil, Russia, India, China and South Africa, have already been created for much the same purposes.

The second fundamental problem in the development of the SCO is its broad agenda stemming from differences among the national agendas of its members including not only security issues but also economic cooperation and some general political issues. This limits the SCO's potential as a security institution, "diluting" the agenda of responding to regional stability threats. At the same time, some members, primarily China, are trying to strengthen the Organisation's economic focus, which can further distract its attention from security problems in the future.

In their Astana Declaration signed at the summit on 8-9 June 2017, the SCO leaders reaffirmed their commitment to creating a SCO development bank promoted by China, and enhancing energy, transport and investment cooperation [SCO Secretariat, 2017]. A statement for the press [SCO Secretariat, 2017] issued after a meeting of the Heads of State Council called for further expert consultations on the creation of a SCO development bank and a development fund intended to provide financial support to joint infrastructure projects, improve transport cooperation, create multimodal logistics centres and introduce information technologies. Russia is also using the SCO to advance its economic agenda. During the summit, Russian President Vladimir Pu- 
tin stressed the importance of coordinated efforts to interlink integration projects in Eurasia by combining the potential of the EAEU, the SCO, ASEAN and China's One Belt, One Road initiative [President of Russia, 2017]. But it is the development of the economic agenda within the SCO which is changing the SCO from a security institution into a more universal organization which runs the risk of becoming a "dormant" body without a clear-cut agenda.

\section{Possible Ways to Build a Comprehensive Eurasian Partnership}

As far as Russia's security interests are concerned, it would be advisable to engage in dialogue with foreign partners on three tracks.

First, in the years to come Russia should pool efforts with China and other members in order to work out a consolidating agenda for the SCO. Priority should be given to fighting international terrorism, political and religious extremism, ensuring security in Afghanistan and preventing its complete collapse.

Strengthening the institutional dimension of the SCO is also important for drawing up its practice-oriented agenda. It would be advisable to introduce the practice of monitoring missions (similarly to the OSCE) as a way to expand the Organisation's scope of activities. Such missions could be authorized to work on the Tajik-Afghan border and possibly in other "hot spots." The work of such missions could be instrumental in "freezing" local conflicts.

Second, it would be advisable to keep expanding the Organisation, first by admitting Iran. The very logic of the SCO's central role as the main security institution in Greater Eurasia suggests its further enlargement even though this may impair its efficiency in the short and medium-term [Karaganov, 2017]. The absence of Iran as a fullfledged member of the SCO runs counter to the logic of a pan-Eurasian security system given Iran's geopolitical importance in fighting terrorism and facilitating a settlement in the Middle East. Its admission all by itself (unlike that of India and Pakistan) will not provoke discontent in the Organisation as Iran has no major disagreements with any of the members. Moreover, its admission as a full member of the SCO will certainly not weaken the Organisation (due to enlargement) but on the contrary could make its work even more effective. In fact, Iran's accession to the SCO will automatically make the fight against terrorism a central uniting issue on the Organisation's agenda, helping to consolidate its members' efforts against ISIS and other terrorist groups.

Third, Russia should work to shift the SCO's focus to security by ridding the Organisation of economic formats and initiatives. Enhancing its economic dimension, as actively proposed by China, would be unadvisable. This would dilute its agenda and transform it from an institution of political cooperation and security into a universal organization without a clear role in the institutional system of Greater Eurasia.

Further, a stronger emphasis on economic aspects would overburden the Eurasian space with economic formats. It would be sensible to pursue only those economic objectives which are closely related to security issues and can benefit Russia. These may 
include facilitating economic development in Afghanistan and engaging it in transportation and logistics projects within Greater Eurasia, as well as coordinating India's and Pakistan's efforts in Belt and Road projects.

Fourth, strengthening the SCO's economic agenda may weaken the EAEU as a central institution in Greater Eurasia's economic space, the creation of which serves Russia's interests. Filling the SCO's agenda with economic issues, let alone strengthening its institutional framework (for example by creating a SCO bank actively promoted by China) may divert at least some of the issues from the EAEU's dialogue formats with third countries into the SCO format.

Fifth, it would be advisable to develop cooperation between the SCO and another key security structure in Greater Eurasia - the CSTO. Although the latter organization is more local than the SCO in terms of security, it should also be regarded as one of the important security institutions in Greater Eurasia. In fact, it is the only security institution in the region where Russia plays an uncontested leading role.

The main structural weakness of the CSTO as a security institution in Greater Eurasia is its poorly developed external contacts and bilateral and multilateral cooperation formats (primarily with the SCO). It would, therefore, be advisable to create and advance external dialogue formats and partnerships between the CSTO and other countries and the SCO in the field of security.

Another important security factor in Greater Eurasia is the coordination of efforts between Russia and ASEAN-centric multilateral formats. From this point of view, the Eurasian process serves the interests of both sides as it allows the SCO to assert itself as a regional security leader and coordinator and breathe a new life into the ARF, the EAS and the ADMM-Plus. This will provide countries in the region with reliable communication channels to respond to growing international threats, primarily terrorism, which is one of the focal points in Russia's foreign policy strategy. Second, one could assume that well-functioning mechanisms to support economic partnership in the region will encourage East Asian countries, primarily ASEAN, to step up their economic cooperation with Russia. This will boost investment in projects in Siberia and Russia's Far East.

In practical terms, it would be advisable to establish cooperation between the ASE$\mathrm{AN}$ and SCO antiterrorist agencies, including joint exercises and exchange of information and coordination between the ASEAN-Russia Joint Working Group on CounterTerrorism and Transnational Crime, the ADMM-Plus Experts' Working Group on Counter-Terrorism and the SCO Regional Anti-Terrorist Structure, with a focus on fighting terrorism and extremism.

Active cooperation with Russia may also help reduce food security threats in the region. Extensive arable land and huge reserves of fresh water in Siberia and the Far East can potentially augment cooperation between Russia and ASEAN [Bordachev et al., 2017]. According to the analytical report "Towards the Great Ocean-2" prepared by the Valdai International Discussion Club, Siberia and Russia's Far East account for $16 \%$ of the world's fresh water reserves [Makarov et al., 2014, p. 45]. This is an advantage that can be used to eliminate the shortage of fresh water in the Asia-Pacific region, 
which in turn may smooth over disagreements over the use of water from the Mekong River, for example. But cooperation in this area should not be viewed as literal trade in water through the construction of pipelines, for this would be costly both economically and environmentally. A. Likhacheva and I. Makarov suggest developing "virtual water" cooperation instead, meaning production processes that require large amounts of water (for example, food, pulp and paper, chemical fibers, non-ferrous metals) [Makarov et al., 2016, p. 266]. Moreover, Russia has large areas of arable land (about 9\% of the world's reserves according to the World Food and Agriculture Organization) [FAO]. This may provide the basis for creating a joint grain fund to be used in the event of possible natural disasters that could destroy crops in the Asia-Pacific region.

Finally, another important advantage of the Eurasian vector is that a shift of transportation trade routes towards the centre of Eurasia as part of the proposed initiatives may make the South China Sea less strategically important and thus help settle the territorial dispute [Kanaev, 2016, p. 315].

In conclusion, coordination between key regional security formats appears to be a necessary element not only for addressing various security problems in the Asia-Pacific region but also for taking concrete steps to build a political agenda for a comprehensive Eurasian partnership.

Political processes in Greater Eurasia are creating an objective demand for advancement and institutionalization of multilateral security cooperation. In the medium and long-term, integration of key security formats in the region such as the SCO, the CSTO and ASEAN-centric platforms (the EAS, the ARF and the ADMM-Plus) will have the greatest potential for implementing the comprehensive Eurasian partnership project and pursuing Russia's strategic interests in the most effective way as part of its pivot to the East.

\section{References}

Association of Southeast Asian Nations (ASEAN) (2015) Chairman's Statement of the 18th ASEANChina Summit. Kuala Lumpur, 21 November. Available at: http://www.asean.org/storage/2015/12/ Chairmans-Statement-of-the-18th-ASEAN-China-Summit-Final.pdf (accessed 17 August 2017).

Bordachev T., Kashin V., Lukin A., Makarov I., Pjatachkova A., Sokolova A., Shumkova V., Stepanov I., Bezborodov A., Safranchuk I., Al'muhamedova N., Van V., Aj V., Jan F., Jan C., Lju Ch., Chzhan Ja. (2017) Preobrazovanie Evrazijskogo prostranstva: obshhie perspektivy v predstavlenii analiticheskih centrov Kitaja, Rossii i Kazahstana [Transformation of the Eurasian Space: General Perspectives in the Representation of the Chinese, Russian and Kazakh Analytical Centres]. Valdai International Discussion Club, p. 26 (in Russian).

Cherian J. (2017) In Shanghai Eight. 7 July. Available at: http://www.frontline.in/world-affairs/inshanghai-eight/article9731163.ece (accessed 30 September 2017).

Denisov I., Safranchuk I. (2016) Chetyre problemy ShOS v svete voprosa o rasshirenii organizatsii [Four Problems of SCO in the Context of the Organisation's Enlargement]. Vestnik MGIMO Universiteta, 
vol. 48, no 3. Available at: http://www.vestnik.mgimo.ru/sites/default/files/pdf/010_mp_denisovie_safranchukia_1. pdf (accessed 30 September 2017) (in Russian).

Food and Agriculture Organization of the UN (FAO) (c. a.) FAOSTAT. Available at: http://www.fao. org/ faostat/en/\#data/GC (accessed 26 August 2017).

Kanaev E. (2016) Russia and ASEAN in Eurasia: Value-Added for Russia-ROK Cooperation. Korea Institute for International Economic Policy, Studies in Comprehensive Regional Strategies Collected Papers (International Edition) 16-15. Available at: http://www.area-studies.ox.ac.uk/sites/sias/files/ documents/KIEP\%20 Davis\%20Russia\%20Europe\%20Asia\%20170418.pdf (accessed 26 August 2017).

Karaganov S., Bordachev T., Bezborodov A., Kashin V., Korolev A., Lihacheva A., Makarov I., Stepanov I., Sokolova A., Shumkova V. (2017) K Velikomu Okeanu - 5: ot povorota na Vostok k Bol'shoj Evrazii [Toward the Great Ocean - 5: From the Pivot to the East to Greater Eurasia]. Valdai International Discussion Club, p. 49 (in Russian).

Lokshin G.M. (2013) ASEAN and Territorial Disputes in the South China Sea. Southeast Asia: Topical Problems of Development, vol. 20, pp. 17-39 (in Russian).

Makarov I.A., Barabanov O.N., Bordachev T.V., Kanaev E.A., Larin V.L., Ryzhkov V.A. (2014) K Velikomu Okeanu - 2, ili rossiiskii ryvok k Azii [Towards the Great Ocean -2 or Russia's Breakthrough to Asia]. Valdai International Discussion Club (in Russian).

Makarov I.A., Makarova E.A., Karaganov S.A., Bordachev T.V., Kanaev E.A., Litvinova Yu. O., Likhacheva A.B., Pestich A.S., Pyatachkova A.S., Sokolova A.K., Stepanov I.A., Shcherbakova A.V. (2016) Povorot na Vostok. Razvitie Sibiri i Dal'nego Vostoka v usloviyakh usileniya aziatskogo vektora vneshnei politiki Rossii [The Turn to the East: The Development of Siberia and the Russian Far East during the Strengthening of the Asian Direction of Russian Foreign Policy]. Moscow: Mezhdunarodnye Otnosheniya (in Russian).

Mikhnevich S.V. (2016) The Glory of Intelligence: China's Smart Power and the Implications for Security in the Asia-Pacific Region. International Organizations Research Journal, vol. 11, no 1, pp. 92-125 (in Russian).

Ministry of Foreign Affairs of Russia (2016) Kontseptsiya vneshnei politiki Rossiiskoi Federatsii (utverzhdena Prezidentom Rossiiskoi Federatsii V.V. Putinym 30 November 2016) [The Concept of Foreign Policy of the Russian Federation (Enacted by the President of Russian Federation V.V. Putin on 30 November 2016)]. Available at: http://www.mid.ru/foreign_policy/official_documents/-/asset_publisher/ CptICkB6BZ29/content/ id/2542248 (accessed 25 March 2017) (in Russian).

President of Russia (2017) Meeting with President of China Xi Jinping. 8 June. Available at: http:// en.kremlin. ru/events/president/news/54733 (accessed 30 September 2017).

Reuters (2017) China Says Iran Membership of Shanghai Security Bloc to be Discussed at Summit. 4 June. Available at: https://www.reuters.com/article/us-china-sco-iran/china-says-iran-membershipof-shanghai-security-bloc-to-be-discussed-at-summit-idUSKBN18W0CD (accessed 30 September 2017).

SCO Secretariat (2017) Statement by the Heads of the Member States of the Shanghai Cooperation Organisation on Joint Counteraction to International Terrorism. Available at: http://eng.sectsco.org/documents/ (accessed 30 September 2017).

Thayer C.A. (2013) ASEAN, China and the Code of Conduct in the South China Sea. SAIS Review of International Affairs, vol. 33, no 2, pp. 75-84. Available at: http://nghiencuuquocte.org/wp-content/ uploads/2014/03/ ASEAN-China-and-the-Code-of-Conduct-in-the-South-China-Sea.pdf (accessed 15 August 2017). 


\title{
Политические институты Большой Евразии: выводы для России ${ }^{1}$
}

\author{
А.С. Королев, В.А. Шумкова
}

Королев Александр Сергеевич - стажер-исследователь Центра комплексных европейских и международных исследований (ЦКЕМИ) Национального исследовательского университета «Высшая школа экономики», аспирант НИУ ВШЭ; Российская Федерация, 119017, Москва, ул. Малая Ордынка, д. 17; E-mail: askorolev@hse.ru

Шумкова Вероника Антоновна - стажер-исследователь Центра комплексных европейских и международных исследований (ЦКЕМИ) Национального исследовательского университета «Высшая школа экономики»; Российская Федерация, 119017, Москва, ул. Малая Ордынка, д. 17; E-mail: vshumkova@ hse.ru

В настоящей статье авторы анализируют сегодняшнее состояние и перспективы развития ключевых институтов в сфере обеспечения региональной безопасности в Евразии. В качестве кейсов в работе выбраны асеаноцентричные механизмы и евразийские, «континентальные» форматы, представленные Шанхайской организацией сотрудничества (ШОС) и Организацией Договора о коллективной безопасности (ОДКБ).

Особый акцент в работе делается на возможности подключения России к многосторонним инициативам 8 сфере безопасности в Евразии с точки зрения продвижения стратегических интересов Москвы, а также реализации потенциала ШОС в качестве структурной опоры зарождающегося геостратегического пространства Большой Евразии.

Авторы приходят к следующему выводу: нынешнее состояние региональных институтов в области безопасности не в полной мере соответствует российским интересам, что вызвано институциональной ограниченностью многосторонних форматов.

В частности, по мнению авторов, основной причиной, не позволяющей асеаноцентричным диалоговым площадкам по вопросам безопасности реализовать свой потенциал в решении поставленных задач, является характер принципов сотрудничества АСЕАН, затрудняющих процесс принятия коллективного решения.

Применительно к ШОС авторы считают, что ключевой проблемой в обозримом будущем может стать достижение консенсуса между государствами-участниками после расширения формата (присоединения Индии и Пакистана) и, как следствие, необходимость трансформации институционального формата под новые реалии.

Авторы приходят к выводу, что в долгосрочной перспективе развитие институциональной среды Большой Евразии с точки зрения обеспечения региональной безопасности целесообразно осуществлять путем тесной координации между ШОС и другими форматами безопасности - ОДКБ и асеаноцентричными площадками.

Ключевые слова: Большая Евразия; Россия; ШОС; ОДКБ; АСЕАН; ВАС; АРФ

Для цитирования: Королев А.С., Шумкова В.А. (2018) Политические институты Большой Евразии: выводы для России // Вестник международных организаций. Т. 13. № 3. С. 70-81 (на русском и английском языках). DOI: 10.17323/1996-7845-2018-03-04.

\section{Источники}

Бордачев Т.В., Кашин В.Б., Лукин А.В., Макаров И.А., Пятачкова А.С., Соколова А.К., Шумкова В.А., Степанов И.А., Безбородов А.А., Сафранчук И.А., Альмухамедова Н., Ван В., Ай В., Ян Ф., Ян Ц., Лю Ч., Чжан Я. (2017) Преобразование Евразийского пространства: общие перспективы в представлении

${ }^{1}$ Статья поступила в редакцию в октябре 2017 г.

Статья подготовлена за счет гранта Российского научного фонда № 17-18-01577 «Формирование Сообщества Большой Евразии и стратегии двустороннего взаимодействия России со странами региона». 
аналитических центров Китая, России и Казахстана. М.: Международный дискуссионный клуб «Валдай».

Денисов И.Е., Сафранчук И.А. (2016) Четыре проблемы ШОС в свете вопроса о расширении организации // Вестник МГИМО-Университета. Т. 48. № 3. Режим доступа: http://www.vestnik.mgimo.ru/sites/default/files/pdf/010_mp_denisovie_safranchukia_1.pdf (дата обращения: 30.09.2017).

Караганов С.А., Бордачев Т.В., Безбородов А.А., Кашин В.Б., Королев А.С., Лихачева А.Б., Макаров И.А., Степанов И.А., Соколова А.К., Шумкова В.А. (2017) К Великому Океану - 5: от поворота на Восток к Большой Евразии. Международный дискуссионный клуб «Валдай».

Локшин Г.М. (2013) АСЕАН и территориальные споры в Южно-Китайском море // Юго-Восточная Азия: актуальные проблемы развития. № 20. С. 17-39.

Макаров И.А., Барабанов О.Н., Бордачев Т.В., Канаев Е.А., Ларин В.Л., Рыжков В.А. (2014) К Великому Океану - 2, или российский рывок к Азии. М.: Международный дискуссионный клуб «Валдай».

Макаров И.А., Макарова Е.А., Караганов С.А., Бордачев Т.В., Канаев Е.А., Литвинова Ю.О., Лихачева А.Б., Пестич А.С., Пятачкова А.С., Соколова А.К., Степанов И.А., Щербакова А.В. (2016) Поворот на Восток. Развитие Сибири и Дальнего Востока в условиях усиления азиатского вектора внешней политики России. М.: Международные отношения.

Министерство иностранных дел России (2016) Концепция внешней политики Российской Федерации (утверждена Президентом Российской Федерации В.В. Путиным 30.11.2016). Режим доступа: http:// www.mid.ru/foreign_policy/official_documents/-/asset_publisher/CptICkB6BZ29/content/id/2542248 (дата обращения: 25.03.2017).

Михневич С.В. (2016) Счастье от разума: «умная сила» КНР и ее влияние на развитие архитектуры безопасности в Азиатско-Тихоокеанском регионе // Вестник международных организаций: образование, наука, новая экономика. Т. 11. № 1. С. 92-125.

ШОС (2017) Информационное сообщение по итогам заседания Совета глав государств-членов Шанхайской организации сотрудничества. Режимдоступа:http://rus.sectsco.org/news/20170609/289250. html (дата обращения: 30.09.2017).

Association of Southeast Asian Nations (ASEAN) (2015) Chairman's Statement of the 18th ASEAN-China Summit. Kuala Lumpur. 21 ноября. Режим доступа: http://www.asean.org/storage/2015/12/ChairmansStatement-of-the-18th-ASEAN-China-Summit-Final.pdf (дата обращения: 17.08.2017).

Cherian J. (2017) In Shanghai Eight. Режим доступа: http://www.frontline.in/world-affairs/in-shanghaieight/article9731163.ece (дата обращения: 30.09.2017).

Food and Agriculture Organization of the UN (FAO) (c. а.) FAOSTAT. Режим доступа: http://www.fao.org/ faostat/en/\#data/GC (дата обращения: 26.08.2017).

Kanaev E. (2016) Russia and ASEAN in Eurasia: Value-Added for Russia-ROK Cooperation. Режим доступа: http://www.area-studies.ox.ac.uk/sites/sias/files/documents/KIEP\%20Davis\%20Russia\%20Europe\%20 Asia\%20170418.pdf (дата обращения: 26.08.2017).

President of Russia (2017) Meeting with President of China Xi Jinping. Режим доступа: http://en.kremlin.ru/ events/president/news/54733 (дата обращения: 30.09.2017).

Reuters (2017) China says Iran Membership of Shanghai Security Bloc to Be Discussed at Summit. Режим доступа: https://www.reuters.com/article/us-china-sco-iran/china-says-iran-membership-of-shanghai-security-bloc-to-be-discussed-at-summit-idUSKBN18W0CD (дата обращения: 30.09.2017).

Thayer C.A (2013) ASEAN, China and the Code of Conduct in the South China Sea. Режим доступа: http:// nghiencuuquocte.org/wp-content/uploads/2014/03/ASEAN-China-and-the-Code-of-Conduct-in-theSouth-China-Sea.pdf (дата обращения: 15.08.2017). 